\title{
Characterization of peroxidase enzyme and detoxification of phenols using peroxidase enzyme obtained from Zea mays $L$ waste
}

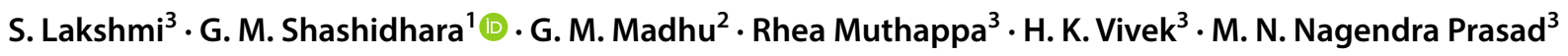

Received: 16 November 2017 / Accepted: 12 September 2018 / Published online: 26 October 2018

(c) The Author(s) 2018

\begin{abstract}
Phenol is one of the greatest menaces among the industrial pollutants. A treatment method which utilizes agricultural wastes in a simple manner has become the need of the hour. In this investigation, details on the extraction, optimization of parameters and study of detoxification potential of the peroxidase enzyme obtained from baby corn waste have been elaborated. The enzyme has been extracted from both corn silk and husk, and studies have been conducted on both the samples. Estimation of amount of protein and enzyme activity has shown promising results, and the conditions optimized are easily attainable at larger scales, making this work feasible for scale-up.
\end{abstract}

Keywords Detoxification $\cdot$ Phenol $\cdot$ Zea Mays $L$ waste $\cdot$ Peroxidase enzyme

\section{Introduction}

Management and processing of the waste from different industries are the major problem in the different parts of the world (Anupama et al. 2013). The harmful impact of molecules that are generated from various different process industries pollutes air and water by its dangerous and mutagenic properties (Busca et al. 2008).

Major organic pollutants include phenol and its derivatives like chlorophenol, cresols, orthophenols, nitro phenols, etc., produced by various industrial activities, such as coal mining, petroleum refining, resin, plastic and pharmaceutical production, wood preservation, metal coating and textile dyeing (Varsha et al. 2011). Production and degradation of pesticides also release huge quantities of phenols and its derivatives to the environment. Phenols are poisonous and harmful to organisms even at low concentrations, and as a result detoxification of phenol has wide prospect. In addition to toxic effects, phenolic compounds also generate an

M. N. Nagendra Prasad

mnnagendraprasad@sjce.ac.in

1 Department of Polymer Science and Technology, JSS S\&TU, SJCE, Mysore, India

2 Department of Chemical Engineering, M.S.R.I.T, Bangalore, India

3 Department of Bio Technology, JSS S\&TU, SJCE, Mysore, India oxygen demand in different sources of waters and pass on taste and smell to water with tiny concentrations of their chlorinated compounds. Ground waters are infected by phenolics as a result of the constant release of these harmful compounds from petrochemical, coal conversion and phenol-generating industries. Owing to its harmful effects, the waste water containing phenolic compounds must be treated before discharging these compounds into the water streams (Roostaei and Tezel 2004).

Methods to remove phenols from industrial wastewater are classified as conventional and advanced methods. Conventional methods include steam distillation, liquid-liquid extraction, adsorption, solid-phase extraction, wet air oxidation, catalytic wet air oxidation and biodegradation for the removal of phenols. Highly developed technologies are also there for treatment of phenol such as electrochemical oxidation, photo-oxidation, ozonation, Fenton reaction, membrane processes and microbial and enzymatic treatment (Mohammadi et al. 2015). Enzymes have several favourable characteristics. They have either narrowed or far-reaching specificity. Due to its specificity, enzymes show their functionality even in mixed compounds. Enzymes extensively alter structural and toxicological properties of contaminants into mild inorganic harmless end products. Furthermore, enzymes may present balance over traditional technologies and also over microbial remediation. All these characteristics turn enzymes into eco-friendly catalysts, and enzymatic

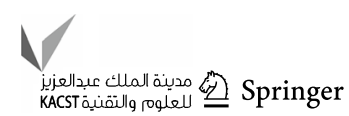


techniques are environmentally affable processes (Rao et al. 2010). Peroxidases are the enzymes that catalyse the variety of organic and inorganic compounds at the expense of peroxide, usually $\mathrm{H}_{2} \mathrm{O}_{2}$. Peroxidases tarnish phenolic compounds to simple radical species, which spontaneously produce insoluble oligo- or polymeric derivatives. These insoluble, polymerized products may be isolated using uncomplicated techniques like sedimentation and filtration techniques (Regalado et al. 2004). Maize silk is the name given to the long styles and stigmas on flower pistils. The stigmas are fine and soft, yellowish to green or purple threads of female flowers. Silk of some maize genotypes contains abundant phenolics, such as flavonoids, tannins and hydroxycinnamic acid esters. Besides their role in defence against pathogens and in host-plant resistance to insects, phenolics are implicated in free radical scavenging, inhibition of lipid peroxidation and defence against UV radiation. Of particular interest in maize are chlorogenic acid and some flavones with similar adjacent hydroxyl ring structure because they are implicated in corn earworm resistance (Elliger et al. 1980; Duffey and Stout 1996) and are considered as silk antibiotics. These adjacent hydroxyls undergo enzymatic oxidation resulting in the production of quinones, which condense with themselves or proteins to produce brown-coloured complexes. Two polyphenol oxidase enzymes, laccase ( $o$ - and $p$-diphenol oxidase, EC 1.10.3.2) and catechol oxidase (o-diphenol oxidase, EC 1.10.3.1), and POD (EC 1.11.1.7) oxidize a large number of aromatic structures at the expense of $\mathrm{O}_{2}$ or $\mathrm{H}_{2} \mathrm{O}_{2}$, respectively (Pütter and Becker 1983; Mayer 1987; Pourcel et al. 2007). Oxidized phenolics protect sensitive plant tissues from biotic and abiotic stress (Hurrell et al. 1982; Duffey and Stout 1996).

Enzymatic method is highly efficient and low cost compared to physical, chemical and microbial methods. Zea mays L (Baby corn) husk and silk are cheap, cost-effective alternative for phenol treatment in effluent water, especially in industries located close to agricultural lands, because the crude phenol-degrading enzyme (most likely, peroxidase) is present in the sample, can be isolated and extracted from both husk and silk and therefore has immense potential in the complete degradation of phenol.

\section{Materials and methods}

\section{Plant material}

Zea mays L (baby corn) sample was obtained from the local market. Corn silk is a common name for the glossy, frail, weak fibres that develop as part of ears of corn (maize); the tuft or tassel of silky fibres protrudes from the tip of the ear of corn. The ear is enclosed in modified leaves called husks.

\section{Chemicals}

The AR-grade chemicals used in this work and supplier details are as follows: ammonium sulphate (Qualigens), calcium chloride (Merck), guaiacol (Srichem), hydrogen peroxide, catechol, phenol (Nice Chemicals), anhydrous sodium carbonate (Rankem), sodium bicarbonate, 4-aminoantipyrine, boric acid, potassium ferricyanide, potassium dihydrogen phosphate (HiMedia Laboratories), di-potassium hydrogen phosphate (S D Fine-Chem Ltd), BSA (Merck), sodium hydroxide (Merck), sodium bicarbonate, copper sulphate, sodium potassium tartrate (Merck) and Folin reagent (Merck).

\section{Methods}

\section{Extraction of crude enzyme}

$100 \mathrm{~g}$ of silk from baby corn was carefully washed with distilled water, drained and ground into coarse paste. It was then filtered through dirt-free muslin cloth, and the filtrate was collected. A specified amount of filtrate was measured, and ammonium sulphate was added to precipitate the proteins (crude enzyme) from the filtrate. The solubility of globular proteins increases upon the addition of salt (ammonium sulphate), an effect termed salting-in. At higher salt concentrations, protein solubility usually decreases, leading to precipitation. This effect is termed salting-out. The filtrate was subjected to stirring for about $2.5 \mathrm{~h}$ followed by cold $\left(4^{\circ} \mathrm{C}\right)$ centrifugation for $15 \mathrm{~min}$ at $8000 \mathrm{RPM}$. The pellets were collected, and the supernatant liquid was reused for the same procedure at different salt concentrations. Five cuts $(0-20 \%, 20-40 \%, 40-60 \%, 60-80 \%$ and $80-100 \%)$ of precipitations were carried out, and the resulting solids (proteins) were stored separately. The same procedure was repeated for the husk sample too.

\section{Dialysis}

Proteins can be separated from salt by dialysis through a partially permeable membrane. Molecules having size significantly higher than the pore diameter are retained inside the dialysis bag, whereas smaller molecules and ions navigate the pores of such a membrane and emerge in the dialysate outside the bag. The crude enzyme solution or the pellets that were extracted were filled in dialysis bags made up of cellulose esters $(3 \mathrm{kDa})$ subjected to magnetic stirring for $48 \mathrm{~h}$ for the removal of salt that was added to precipitate the proteins. The partially purified enzymatic solutions were then obtained. 


\section{Quantification of protein}

"Lowry's test (1951) was used for estimation of amount of protein in the solutions". The Lowry's test has been one of the most commonly used methods for determining protein concentration. Folin reagent together with a copper sulphate solution is mixed with a protein solution, and it results a blue purple product, which can be quantified by UV spectrophotometer at $640 \mathrm{~nm}$.

\section{Estimation of enzyme activity}

Peroxidase activity in the extracts was measured as described by Loukili et al. (1999). Enzyme activity was tested using Guaiacol as substrate where the effect of peroxidase enzyme on guaiacol in the presence of hydrogen peroxide was tested. UV spectrophotometric method of analysis was used at a wavelength of $470 \mathrm{~nm}$ to quantify the activity on the basis of the production of coloured complex due to the action of the enzyme.

\section{Optimization of physical parameters}

Once the presence and activity of the peroxidase enzyme were determined, various parameters like volume of enzyme, concentration of the substrate, temperature and $\mathrm{pH}$ were varied and its effects were tested. The volume of enzyme solution was varied between 10 and $200 \mu$, concentration of the substrate between 20 and 200 millimoles, the temperature between -20 and $40{ }^{\circ} \mathrm{C}$ and the $\mathrm{pH}$ between 3.5 and 9 .

\section{Enzyme kinetics}

Both Michaelis-Menten and Lineweaver-Burk plots were plotted, and the enzyme kinetics was studied. The concentration of guaiacol, which is taken as a substrate, was varied, and the activity was tested. Substrate concentration was varied between 20 and 200 millimoles. The plot of activity versus substrate concentration gave the Michaelis-Menten data, and the double reciprocal plot of the same was used as the Lineweaver-Burk plot.

\section{Detoxification}

The partially purified enzyme was used to detoxify phenol in the presence of hydrogen peroxide. The study was conducted at different concentrations of hydrogen peroxide and for different time periods. Quantification of phenol at both the initial and final stages was carried out by the 4-AAP method, where a reaction mixture formed a coloured complex with the phenol in the solution. The amount of phenol was indirectly estimated by the amount of coloured complex produced. This was analysed by UV spectrophotometric

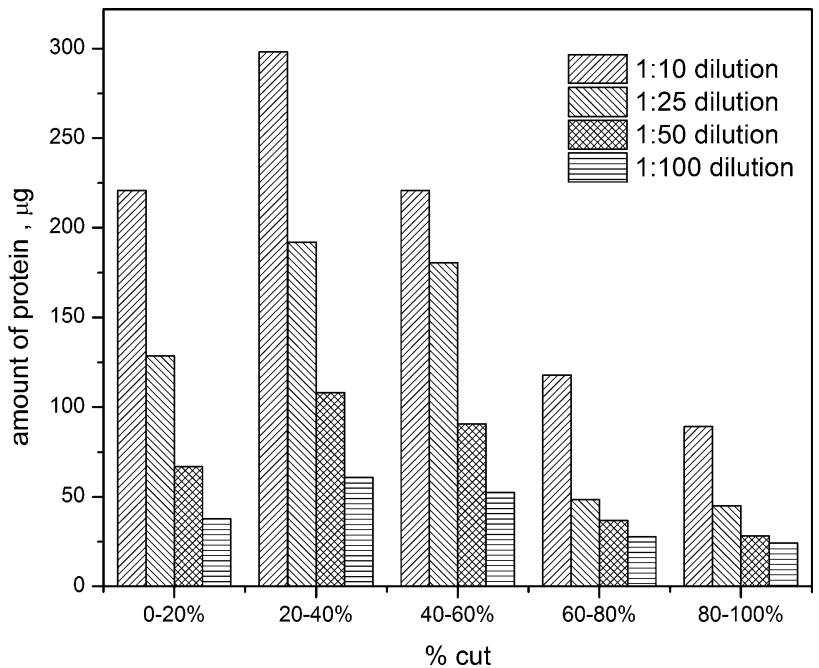

Fig. 1 Amount of protein in $\mu \mathrm{g}$ for different cuts at different dilutions for baby corn silk

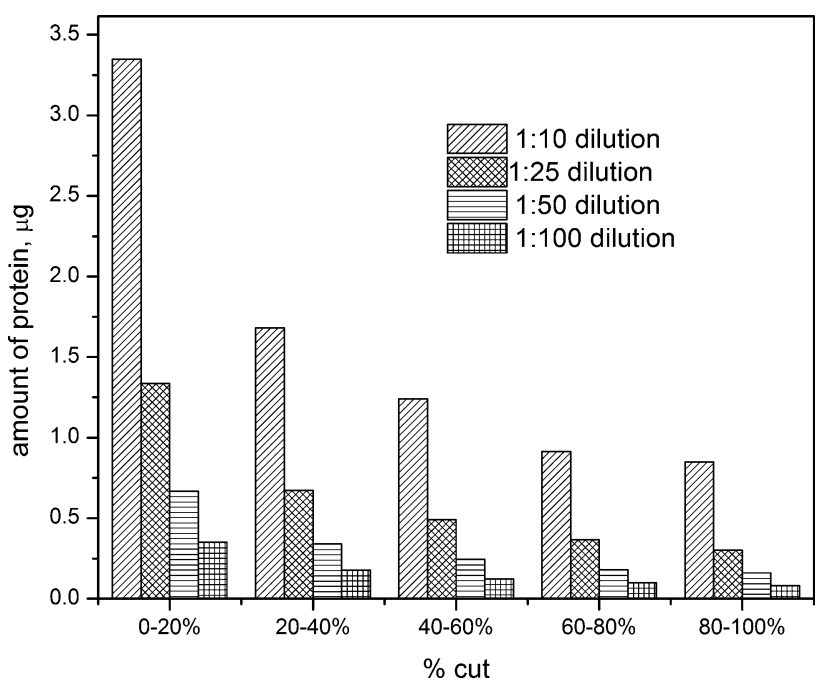

Fig. 2 Amount of protein in $\mu \mathrm{g}$ for different cuts at different dilutions for baby corn husk

analysis at $520 \mathrm{~nm}$ using Agilent Technologies (USA) Cary 60 UV-Visible spectrophotometer.

\section{Results and discussion}

\section{Estimation of total protein in the enzyme extract}

Lowry's test was conducted for the extract containing the enzyme at different dilutions ranging from 1:10 to 1:100. As a drastic decrease in amount of protein was found with increased dilutions, 1:10 was taken as optimum dilution rate for both the silk and husk samples (Figs. 1,2). In the same

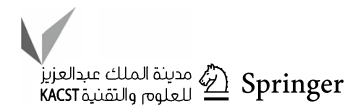


test, the cut containing the highest amount of protein was also found. The maximum amount of protein was found in $20-40 \%$ cut of the silk sample, i.e., $298.1 \mu \mathrm{g} / \mathrm{ml}$ of the extract (Fig. 1), and in 0-20\% cut of the husk extract, i.e., $3.34 \mu \mathrm{g} / \mathrm{ml}$ of the extract (Fig. 2).

\section{Optimization of cuts depending on enzyme activity}

An assay using guaiacol as the substrate was conducted to test the enzyme activity of the silk and husk samples. As seen in the graph, for both the samples, maximum activity was seen in $60-80 \%$ cut (Figs. 3,4 ) as the enzyme was in purified state compared to other cuts. Even though protein content was more in $20 \%$ cut, activity was good in purified sample.

\section{Optimization of temperature for the highest activity}

Usually peroxidases have an extensive temperature range within which their activity is maintained (Gómez et al. 2006). The effect of temperatures on enzyme activity for both the samples was tested. The test samples were incubated at temperature ranging between -20 and $40{ }^{\circ} \mathrm{C}$. At temperatures below room temperature, the rate of activity was higher, and at $-20{ }^{\circ} \mathrm{C}$ the activity reached its peak (Fig. 5). When the temperature increases, the activity began to decline, and inactivation was observed above room temperature. In fact, the enzyme activity was completely inactivated after boiling the extract. "Rodrigo et al. (1996) have observed the opposite reaction in case of peroxidase of fresh asparagus". Zea Mays peroxidases are found to be active at $-20{ }^{\circ} \mathrm{C}$. The optimum temperature of $4{ }^{\circ} \mathrm{C}$ of the Zea Mays peroxides was similar to that of polyphenoloxidases of Amasya apple (Oktay et al. 1995). These results confirm that

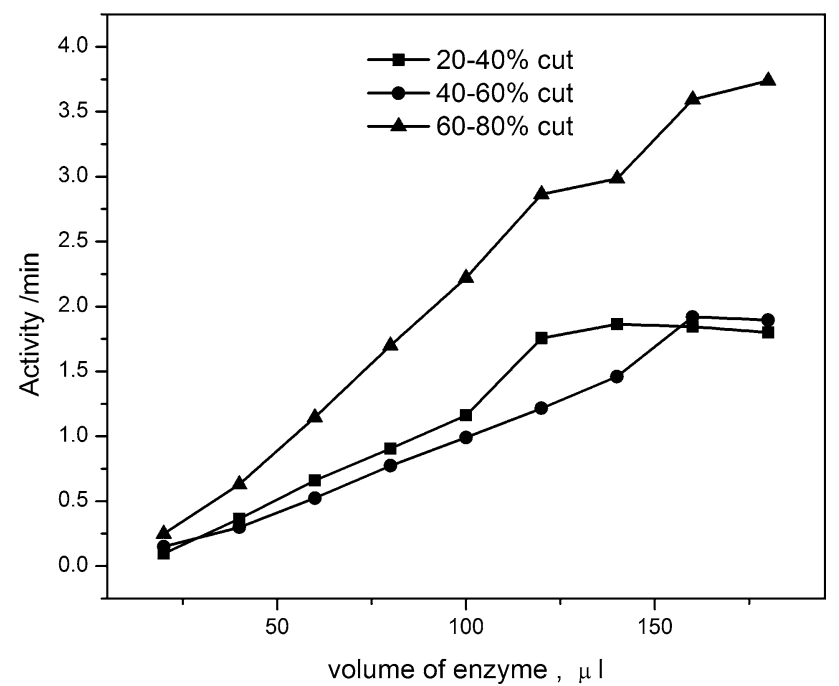

Fig. 3 Optimization of cuts and enzyme volume for baby corn silk

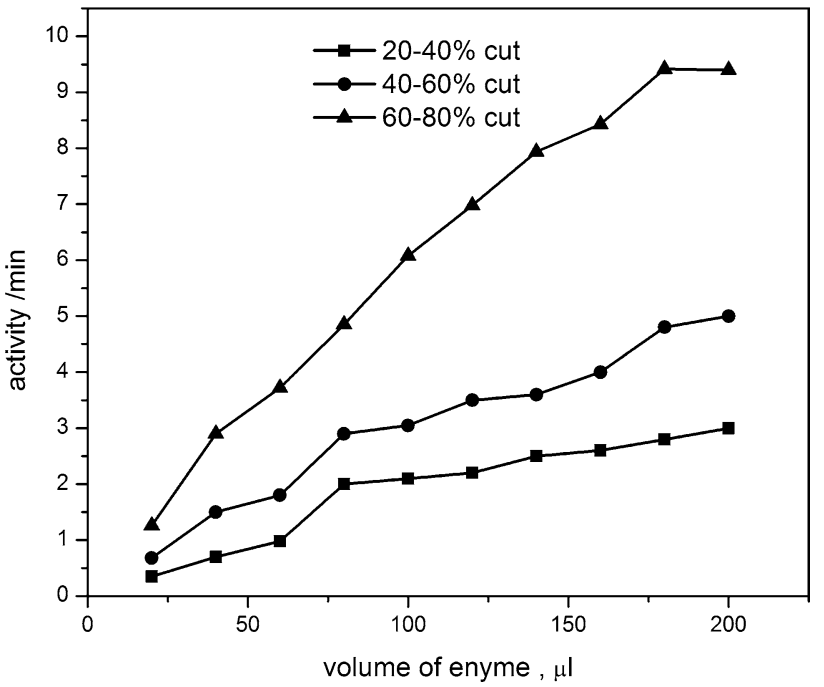

Fig. 4 Optimization of cuts and enzyme volume for baby corn husk

Zea Mays peroxidases are not heat resistant, indicating that heat treatments are not required for Zea Mays peroxidase.

\section{Optimization of $\mathrm{pH}$ for the highest activity}

Peroxidase activity is $\mathrm{pH}$ dependent (Fig. 6). The maximum enzyme activity for silk peroxidase was observed at $\mathrm{pH} 6.5$ and decreased when the $\mathrm{pH}$ was reduced or increased; the drop was sharper in the alkaline than in the acid range for silk peroxidase (Fig. 6). Maximum activity of silk peroxidase was observed at a slightly acidic $\mathrm{pH}$, near $\mathrm{pH} 6$ as observed for strawberry peroxidase (Civello et al. 1995). The maximum enzyme activity for corn husk was observed

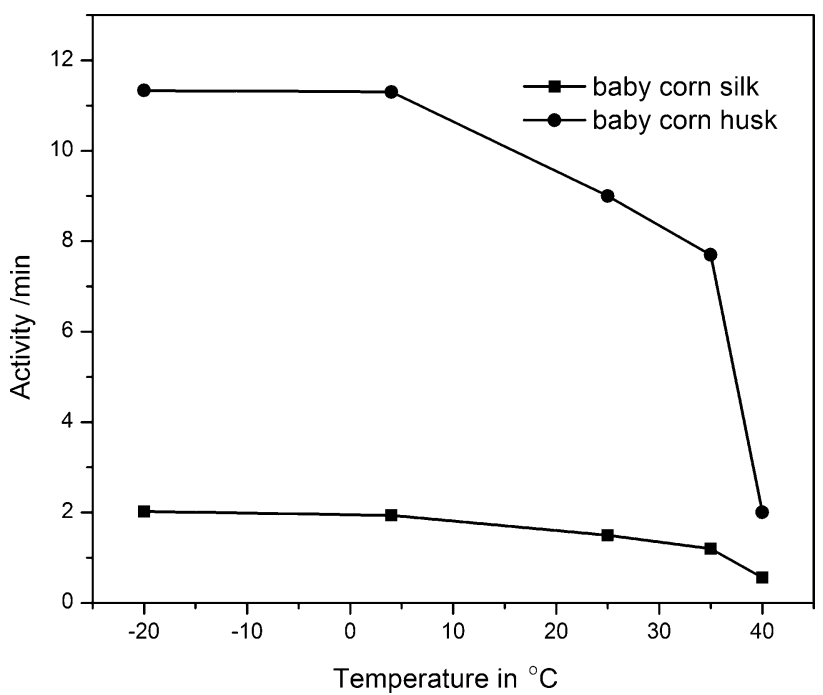

Fig. 5 Optimization of temperature for bay corn silk and husk 


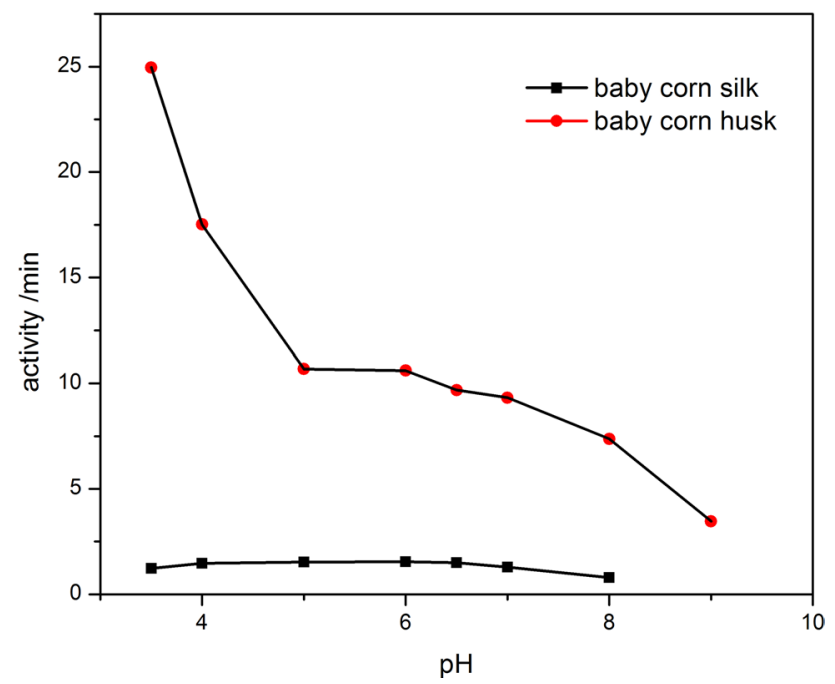

Fig. 6 Optimization of $\mathrm{pH}$ for bay corn silk and husk

at highly acidic range ( $\mathrm{pH} 3.5)$ and decreased when the $\mathrm{pH}$ was increased. The drop was more in the alkaline range for husk peroxidase (Fig. 6). These results show that peroxidase activity is more effectively inhibited in an acid than in an alkaline pH. Work done by Kalaiarasan and Palvannan 2014 indicate that stabilized horse radish peroxidase displayed highest activity at $\mathrm{pH} 4.2$ indicating the activity of peroxidase at acidic conditions. The differences in optimum $\mathrm{pH}$ for peroxidase activity depended on the various parameters such as plant sources, extraction methods, purity of the enzyme, buffers and substrates as reported by Sellés-Marchart et al. (2006).

\section{Enzyme kinetics}

The enzyme kinetics was studied by applying Michaelis-Menten model to the present system. For this purpose, the enzyme activity at different substrate concentrations was noted. The Michaelis-menten graph (Figs. 7, 8) was plotted using Prism-Graphpad software to evaluate of $K_{m}$ and $V_{\max }$ of the samples.

Zea Mays peroxidases showed first-order reaction kinetics. The $K_{m}$ and $V_{\max }$ values were calculated for peroxidase reaction with the substrate using Michaelis-Menten equation. Values of their $K_{m}$ and $V_{\max }$ were found to be 1.81 and 32.87 and 21.44 for silk and 50.32 for husk, respectively. High $R^{2}$ values 0.9905 and 0.9804 were observed for Lineweaver-Burk plot for silk and husk peroxidases which indicates better fit of the data to straight line (Fig. 9). From the Lineweaver-Burk plot, depending on $R^{2}$ values it was found that both peroxidases show almost similar kinetic properties. Because of these significant characteristics, Zea

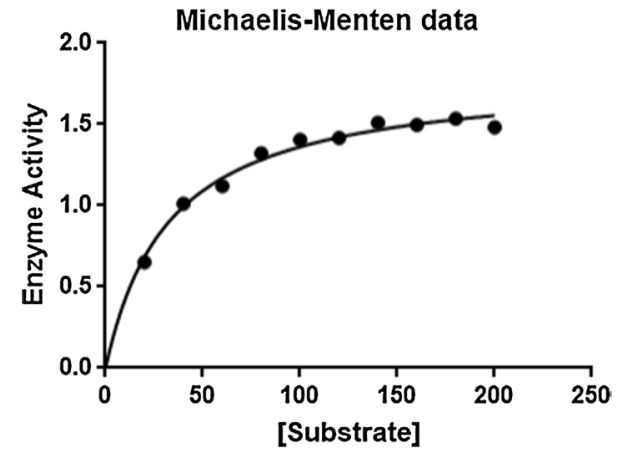

Fig. 7 Michailis-Menten silk peroxidase

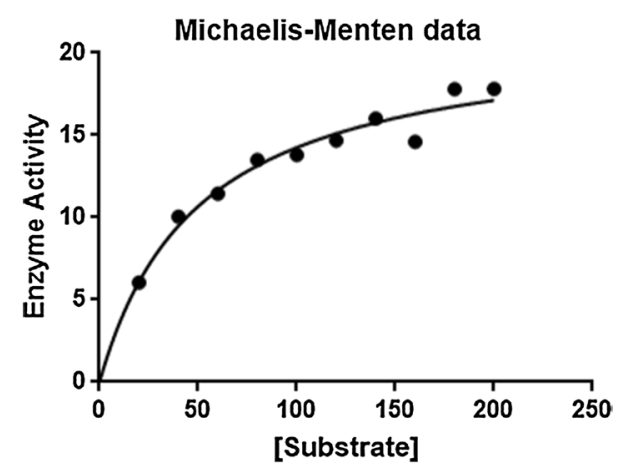

Fig. 8 Michailis-Menten husk peroxidase

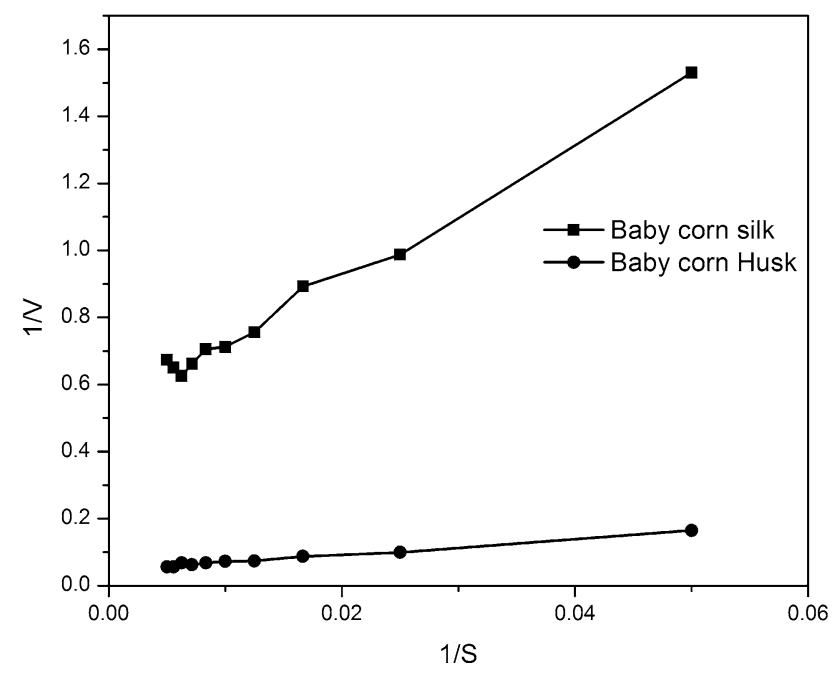

Fig. 9 Lineweaver-Burk plot for silk and husk peroxidases

Mays peroxidases may be used as a potential enzymatic source. 


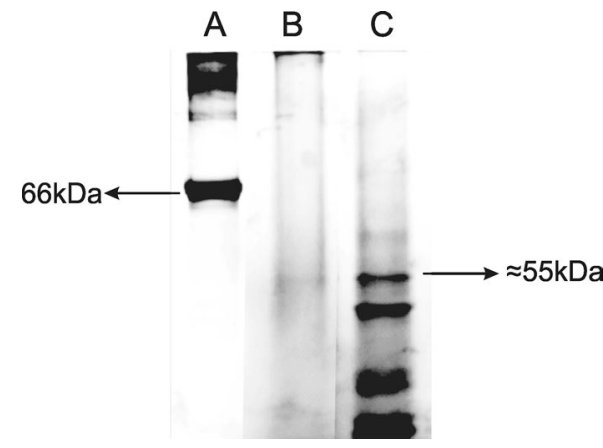

Fig. 10 Electrophoretic pattern of crude and peroxidase enzyme obtained from Zea mays $L$ waste

\section{Molecular weight determination}

SDS-PAGE was carried out according to the method of Laemmli (1970) with $10 \%$ polyacrylamide gel in a vertical slab gel apparatus for crude enzyme fraction $(50 \mu \mathrm{g})$ from baby corn husk and baby corn silk $(50 \mu \mathrm{g})$. Fractions to be analysed by SDS-PAGE were mixed with equal volumes of $2 \times$ non-reducing sample buffer, and the mixture was heated for $1 \mathrm{~min}$ at $70{ }^{\circ} \mathrm{C}$ and cooled. The samples were loaded onto the wells of $4 \%$ stacking gel and were resolved in $10 \%$ polyacrylamide gel at $75 \mathrm{~V}$ using the regular SDS tank buffer. After reaching the maximum electrophoretic front, the power supply was stopped. The bands were visualized by staining with Coomassie Brilliant Blue $R-250$.

SDS-PAGE of $15 \mu \mathrm{g}$ of standard BSA protein (Lane A), $50 \mu \mathrm{g}$ of crude enzyme fraction from baby corn husk (Lane B) and $50 \mu \mathrm{g}$ baby corn silk (Lane C), under non-reducing condition, was carried out. Electrophoretic pattern of crude and peroxidase enzyme obtained from Zea mays $L$ waste suggests that baby corn silk protein contains $\approx 55 \mathrm{kDa}$ peroxidase enzyme (Fig. 10). Nevertheless, further advance techniques should be used to warrant the accurate molecular weight of the peroxidase using mass spectrometry.

\section{Thermodynamic concept of enzyme kinetics}

Activation energy was calculated using Arrhenius plot. The enthalpy was calculated using van't Hoff's equation. Change in Gibbs free energy and change in entropy were calculated using the fundamental property relations in thermodynamics. The results are listed in Table 1 . The results indicate the enzymatic reaction of crude extract of husk and silk is promising $(\Delta G<0)$, non-spontaneous $(\Delta S<0)$ and exother$\operatorname{mic}(\Delta H$ is negative).
Table 1 Thermodynamic properties

\begin{tabular}{lllll}
\hline Species & $E(\mathrm{~kJ})$ & $\Delta G(\mathrm{~kJ})$ & $\Delta H(\mathrm{~kJ})$ & $\Delta S(\mathrm{~kJ})$ \\
\hline Silk & $-10,558$ & -342.26 & -10.558 & -1.41 \\
Husk & $-14,561$ & -353.28 & -14.561 & -1.92 \\
\hline
\end{tabular}

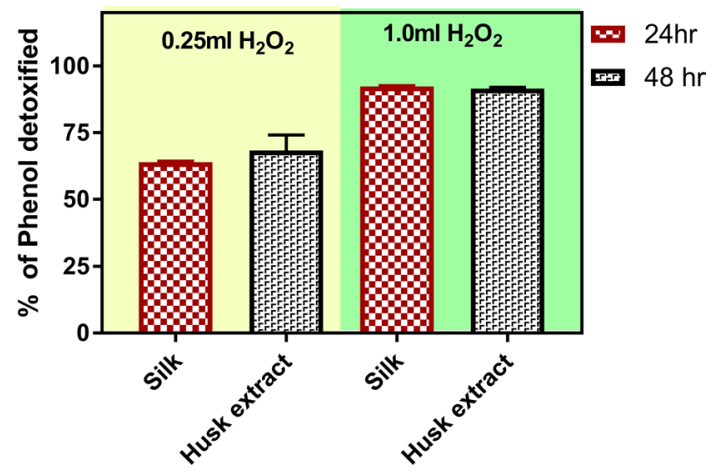

Fig. 11 Percentage detoxification studies

\section{Detoxification studies}

Once the physical parameters and enzyme kinetics were studied, the partially purified enzyme sample can be used to study the extent of detoxification of synthetic phenol. In the reaction mixture, the presence of hydrogen peroxide was vital, as it acts as a source for free molecular oxygen without which peroxidase enzyme cannot act efficiently. Hence, studies were conducted using $1 \mathrm{ml}$ of synthetic phenol with varying concentration of hydrogen peroxide for $24 \mathrm{~h}$ nearly $90 \%$ of phenol was detoxified in the presence of hydrogen peroxide (Fig. 11).

\section{Conclusion}

Considering all the optimized conditions and the extent of detoxification, it can be concluded that the peroxidase enzyme obtained from Zea mays waste can be used as an effective alternative to other methods. The enzymes obtained from both silk and husk show similar activity. However, husk sample can be obtained in bulk. Both the samples can be used together as they are easy to procure and feasible to be used in an industrial scale.

Open Access This article is distributed under the terms of the Creative Commons Attribution 4.0 International License (http://creativeco mmons.org/licenses/by/4.0/), which permits unrestricted use, distribution, and reproduction in any medium, provided you give appropriate credit to the original author(s) and the source, provide a link to the Creative Commons license, and indicate if changes were made. 


\section{References}

Anupama S, Pradeep NV, Hampannavar US (2013) Anaerobic followed by aerobic treatment approaches for Spentwash using MFC and RBC. Sugar Tech 15(2):192-202

Busca G, Berardinelli S, Resini C, Arrighi L (2008) Technologies for the removal of phenol from fluid streams: a short review of recent developments. J Hazard Mater 160:265-288

Civello PM, Martínez GA, ChaveS AR, Añón MC (1995) Peroxidase from strawberry fruit (Fragaria ananassa Duch) partial purification and determination of some properties. J Agric Food Chem 43:2596-2601

Duffey SS, Stout MJ (1996) Antinutritive and toxic components of plant defense against insects. Arch Insect Biochem. 32:3-37

Elliger CA, Chan BG, Waiss AC (1980) Flavonoids as larval growth inhibitors. Naturwissenschaften 67:358-360

Gómez JL, Bódalo A, Gómez E, Bastida J, Hidalgo AM, Gómez M (2006) Immobilization of peroxidases on glass beads: an improved alternative for phenol removal. Enzyme Microb Technol 39(5):1016-1022

Kalaiarasan E, Palvannan T (2014) Removal of phenols from acidic environment by horseradish peroxidase (HRP): aqueous thermostabilization of HRP by polysaccharide additives. J Taiwan Inst Chem Eng 45(2):625-634

Laemmli UK (1970) Cleavage of structural proteins during the assembly of the head of bacteriophage T4. Nature 227(6):80-85

Loukili A, Limam F, Ayadi A, Boyer N, Ouelhazi L (1999) Purification and characterization of a neutral peroxidase induced by rubbing tomato internodes. Physiol Plant 105:2431

Lowry OH, Rosebrough NJ, Farr AL, Randall RJ (1951) Protein measurement with the folin phenol reagent. J Biol Chem 193:265 (The original method)

Mayer AM (1987) Polyphenol oxidases in plants recent progress. Phytochentistry $26(\mathrm{I}): 1-20$
Mohammadi S, Kargari A, Sanaeepur H, Abbassian K, Najafi A, Mofarrah E (2015) Phenol removal from industrial wastewaters: a short review. Desalin Water Treat 53:2215-2234

Oktay M, Küfrevioðlu I, Kocaçalipkan I, Pakiroðlu H (1995) Polyphenoloxidase from Amasya apple. J Food Sci 60:494-496

Pütter J, Becker R (1983) Methods of enzymatic analysis, vol III, 3rd edn. Verlug Chemie, pp 286-293

Pourcel L, Routaboul JC, Cheynier V, Lepiniec L, Debeaujon I (2007) Flavonoid oxidation in plants: from biochemical properties to physiological functions. Trends Plant Sci 12:29-36.

Rao MA, Scelza R, Scotti R, Gianfreda L (2010) Role of enzymes in the remediation of polluted environments. J Soil Sci Plant Nutr 10(3):333-353

Regalado C, Garcia-Almendarez B, Duarte-Vasquez M (2004) Biotechnological applications of peroxidases. Phytochemistry 3:243-256

Rodrigo C, Rodrigo M, Alvarruiz A, Frígola A (1996) Thermal inactivation at high temperatures and regeneration of green asparagus peroxidase. J Food Prot 59:1065-1071

Roostaei N, Tezel FH (2004) Removal of phenol from aqueous solutions by adsorption. J Environ Manag 70:157-164

Sellés-Marchart S, Casado-Vela J, Bru-martinez R (2006) Isolation of a latent polyphenol oxidase from loquat fruit (Eriobotrya japonica Lindl.) Kinetic characterization and comparison with the active form. Arch Biochem Biophys 446:175-185

Varsha YM, Naga Deepthi CH, Chenna S (2011) An emphasis on xenobiotic degradation in environmental clean up. J Bioremediation Biodegrad S11:1

Publisher's Note Springer Nature remains neutral with regard to jurisdictional claims in published maps and institutional affiliations. 